\title{
Relationship between Principal Supervision in Increasing the Job Satisfaction of Private Junior High School Teachers in East Bogor District
}

\author{
Yudhie Suchyadi $^{*}$, Nurjanah $\left.{ }^{* *}\right)$ \\ ${ }^{*}$ Universitas Pakuan, Bogor, Indonesia \\ ${ }^{* *)}$ SMPN 3, Bogor, Indonesia \\ Corresponding Author: ydhie.schyadi@gmail.com
}

\begin{abstract}
In general, this study aims to examine teacher job satisfaction and variables that have a relationship with teacher job satisfaction, in this case is the supervision of the principal and efforts to improve teacher job satisfaction. The method used in this study is a survey method with a correlational approach. The research variable consists of independent variables, namely the supervision of the principal, with the dependent variable namely teacher job satisfaction. This research was conducted in private junior high schools in Bogor Timur sub-district, Bogor City. Research data collection was carried out by distributing questionnaires to 186 respondents who had been selected as samples. The results of the questionnaire were collected and recorded in order to analyze the data to test the research hypothesis and to determine the strength of the relationship between the supervision of the principal and teacher job satisfaction. To test the research hypothesis and to determine the strength of the relationship between the supervision of the principal and teacher job satisfaction, data were analyzed using statistical tests in the form of correlation and simple linear regression, and multiple correlations and regression. Hypothesis testing was carried out at significance level $\alpha=0.05$. This study yields the main conclusion that there is a positive relationship between supervision of the principal and teacher job satisfaction, meaning that the higher the supervision of the principal, the higher the teacher job satisfaction is indicated by the regression equation $\hat{\mathrm{Y}}=74.46+0.53 \mathrm{X}_{1}$ and the correlation coefficient $\mathrm{ry}_{1}=0.520$. Based on the findings, the teacher's job satisfaction can be improved through supervision of the principal.
\end{abstract}

Keywords: Principal Supervision, Teacher Job Satisfaction.

\section{INTRODUCTION}

Education is the most important factor and a top priority that requires serious attention from all parties, because education is a determinant of the nation's progress in the future. National goals and ideals, for the intellectual life of the nation is contained in the 1945 Constitution. The government together with the community continues to seek the development of education for the realization of an independent, superior and ready nation to face the globalization world (Suchyadi, 2017).

Increasing job satisfaction for teachers is very important, because it involves the problem of the work of teachers which is one step in improving the quality of service to students. Aspects related to teachers are related to the image/quality of teachers and welfare. One of the things that should be considered how efforts to improve the quality of teachers is by increasing their job satisfaction, because with teacher job satisfaction that increases, the teacher will try to improve the profession and its quality so that the expected success of education will be achieved.

Job satisfaction is influenced by many factors and one of them is supervision of the principal. This is based on the assumption that teachers work in addition to expecting rewards both material and non-material but they also want a climate that suits their expectations such as openness in the organization, working conditions, attention, support, awards, promotion opportunities, decent income and a sense of fairness from the principal because not all leaders give awards to teachers who have performed well or show good performance, and lack the opportunity to develop themselves. This can result in teachers acting late, sometimes not going to school, not being responsible, not working and motivating to work. If left unchecked it will have an impact on the teacher's work behavior in educating students in school which in turn will lead to a decrease in the overall quality of education. Based on the above thoughts, it is felt necessary in this study to 
study or examine teacher job satisfaction associated with other variables.

The study was conducted in East Bogor Subdistrict and the respondents in the study were private junior high school teachers with a foundation teacher status, the variables studied were limited to independent variables, namely the supervision of the principal and the dependent variable was teacher job satisfaction.

Based on the background and limitation of the above problems, problems can be formulated as follows: Is there a relationship between the supervision of the principal and teacher's job satisfaction?

\section{The Teacher Job Satisfaction}

According to J. Wood, J. Wallace, and R.M. Zeffane (2001), which is supported by the opinion of Stephen P. Robbins (2000), job satisfaction is the extent to which individuals feel positive or negative about their work. The indicators put forward are: a) work, namely responsibilities, interests, and developments; b) relationships with colleagues, namely a harmonious relationship and mutual respect; d) promotion opportunities, namely opportunities for further progress; and e) payment, that is, the fee suggested is sufficient and fair compared to other fees received.

Along with the previous opinion, according to Fred Luthan (2011), job satisfaction is the result of employee perceptions of how well his job provides things that are considered important. Indicators that are stated, namely: a) the work itself, namely the work that provides an interesting task, the opportunity to learn, and the opportunity to accept responsibility, b) salary, namely the amount of wages received and the rate at which this is considered as considered appropriate compared to others in the organization, c) promotion opportunities, where opportunities are given to advance in the organization, d) supervision, the ability of supervisors to provide technical assistance and behavioral support, e) co-workers is the extent to which coworkers are technically clever and support socially.

According to Kreitner and Kinicki (2005), there are five factors that can influence the emergence of job satisfaction, namely:

a. Need Fulfillment, job satisfaction is determined by the extent to which the characteristics of the job provide opportunities for individuals to realize their personal values.

b. Discrepancies, job satisfaction reflects the gap between what is expected and what is obtained by individuals from their work. If expectations are greater than what is received, the individual will be dissatisfied. Conversely, it is estimated that individuals will be satisfied if they receive benefits above their expectations.

c. Value attainment (Job Satisfaction), job satisfaction is the result of the perception of the work providing fulfillment of important individual work values. d. Justice (Equity), job satisfaction is a function of how fair individuals are treated at work.

e. Genetic Components (Dispositional Components), some employees are satisfied with the work environment, some are not. This means that job satisfaction is a function of personal nature and genetic factors, which shows that each individual has different significance in the work environment.

T. Hani Handoko (1985) argued that job satisfaction is a pleasant or unpleasant emotional state with which employees view their work. This is evident in the positive attitude of employees towards work and everything faced in the work environment, because it affects the level of absenteeism, workforce turnover, morale, complaints, and other personnel issues.

Based on the above description of the theory, it can be concluded that job satisfaction is the attitude and feelings of the teacher towards his work related to the work situation, rewards, relationships with superiors, interpersonal cooperation and other matters concerning physical and psychological.

\section{The School Principal Supervision}

H. Syaiful Sagala (2010) stated that supervision of the principal is a series of efforts to improve the teaching and learning situation such as assistance for teachers in carrying out teaching, to help students to be better at learning. But in reality in the eyes of the public there are still many people who think that the supervision of the principal is identical to the supervision that smells of inpection. Whereas in general supervision means efforts to help teachers so that teachers can help students learn to be better. Practice supervision is the development of useful theories to pay attention to aspects of instrumental leadership in instructional, more tactical and referring to tool development the need to achieve certain goals for the supervisor.

According to Burton (1978), supervision is aimed at improving and improving the quality of teaching, fostering existing teaching programs as well as possible, so that there is always an effort to improve the factors that influence the learning process of students. The main function of supervision is not just repair and learning, but to coordinate, stimulate, and encourage the growth of the teaching profession.

Improving the teaching and learning situation can be done by supervision by the principal. The principal carries out his duties as a supervisor, expected to act as a dynamic consultant and able to prepare activities, both physical and psychological forms, such as education, training, instruction, counseling, advice, encouragement that can help subordinates, in improving the ability to carry out assignments and adjust to developments.

According to Daryanto (2001) in general supervision activities follow the characteristics, namely providing assistance to members of school organizations to develop better processes / activities in 
an effort to improve the quality of education. Educational supervision can develop better educational processes, these supervision characteristics include:

1. Supervision treats humans as human beings as a whole both as individuals, social or God's creatures,

2. Supervision is directed to improve the quality of school organization activities,

3. Supervision should be carried out in consultation, mutual respect, willing to accept the opinions of others and express their own opinions.

4. Supervision should pay attention to the welfare of personnel which includes their individual and social needs,

5. Supervision should be carried out by people who have received education or training in the field of supervision.

The supervision characteristics describe activities that are oriented towards humanity and awareness in carrying out work tasks that are charged without any sense of coercion that is fetter, but directs supervision to achieve educational goals that have been jointly determined.

In principle, supervision activities are always extended to each organization, these activities aim to create working conditions and develop the behavior of members of the organization necessary for the achievement of the organization's goals effectively.

Based on the above theoretical studies it can be concluded that the supervision of the principal is an effort made by the principal in fostering, encouraging and directing teachers to be able to achieve educational goals effectively.

\section{RESEARCH METHODS}

In general, this study aims to examine the supervision of principals and variables that have a relationship with the supervision of the principal, in this case is the job satisfaction of teachers.

Specifically this research aims to find out: Relationship between school principal supervision and job satisfaction. The method used in this study is a survey method with a correlational approach. The research variable consists of independent variables, namely the supervision of the principal $\left(\mathrm{X}_{1}\right)$ with the dependent variable namely teacher job satisfaction $(Y)$.

In order to obtain data in the field a questionnaire was prepared based on the indicators in the research variable. The primary data needed is data regarding the supervision of the principal with the dependent variable, namely the job satisfaction of teachers of private junior high schools in East Bogor District.

\section{RESULTS AND DISCUSSION}

Based on the results of hypothesis testing, it is proven that the proposed hypothesis can be received significantly. Overall this study shows that there is a positive relationship between: 1) the relationship between the Principal Supervision and Job Satisfaction, the functional relationship formed between the independent variable and the dependent variable shows that Job Satisfaction is the result of the Principal Supervision variable. The description of the hypothesis is explained as follows.

\section{Relationship Between Principal Supervision (X1) with Job Satisfaction (Y)}

The results of the study show that there is a positive relationship between the Principal Supervision and Job Satisfaction. This is indicated by the correlation coefficient $\left(\mathrm{ry}_{\cdot 1}\right)$ of 0.52 which is stated to be very significant. The Principal's Supervision Contribution to Job Satisfaction was $26.6 \%$ which was stated by the coefficient of determination $\left(\mathrm{r}^{2} \mathrm{y}_{\cdot 1}\right)$ of 0.266. The Principal Supervision's partial correlation coefficient (with controlled Emotional Intelligence variables) is 0.47 which is stated to be very significant. Based on simple linear regression equation $\hat{\mathrm{Y}}=74.46+0.53 \mathrm{X}_{1}$, it is predicted that each increase in one Principal Supervision score will cause an increase of 0.53 Job Satisfaction scores at a constant of 74.46. The results of this study conclude that the Principal Supervision possessed gives a positive contribution that has a significant effect on Job Satisfaction.

This is in accordance with the theory put forward by Burton. Supervision of the principal is an improvement and improvement of the quality of teaching, fostering the best teaching programs, so that there is always an effort to improve the factors that influence the learning process of students. The main function of supervision is not just repair and learning, but to coordinate, stimulate, and encourage the growth of the teaching profession.

Thus the findings of facts and data in the analysis of this study increasingly support the previous findings regarding the existence of a strong relationship between the Principal Supervision on Job Satisfaction either directly or indirectly. Based on the results of the research and discussion above, it can be indicated that one of the efforts to improve Job Satisfaction is to increase or develop the Supervision of the Principal. Based on the results of the research stated above, it can be concluded that the Principal Supervision provides a positive contribution that significantly affects Job Satisfaction.

\section{CONCLUSION}

From the results of testing the first hypothesis, illustrates that there is a positive and very significant relationship between the Principal Supervision $\left(\mathrm{X}_{1}\right)$ and Teacher Job Satisfaction (Y). The regression equation between these two variables is $\hat{Y}=74.46+0.53 X_{1}$, which means that each addition of one unit of the Principal Supervision variable will cause an increase in the Teacher Job Satisfaction variable of 0.53 at a constant 
of 74.46. The degree of closeness of the relationship resulted in a correlation coefficient $\left(\mathrm{ry}_{1}\right)$ of 0.52 . The magnitude of the contribution of the Principal Supervision variable in explaining Teacher Job Satisfaction is indicated by the coefficient of determination $\mathrm{r}^{2} \mathrm{y}_{1}=0.226$ or $22.6 \%$ remaining $77.4 \%$ Teacher job satisfaction is influenced by other factors.

\section{REFERENCES}

Burton, W. H. and Brueckner, L. J. 1978. SupervisionA Social Process. New York: Appleton-CenturyCrofts, Inc.

J.Wood, J.Wallace and R.M. Zeffane. 2001. Organisational Behavior: A Global Perspective, 2nd Edittion Milton, Qld: John Wiley \& Sons Austalia, Ltd.

Kreitner, Robert and Angelo Kinicki. 2005. Perilaku Organisasi (Orgaizational Behavior). Jakarta: Salemba Empat.

Luthans, Fred. 2011.Organizational Behavior 12th Ed. New York: McGraw-Hill.

Luthans, Fred dan Doh, Jonathan P. 2012. International Management. 8th Ed. New York: McGraw-Hill.

M. Daryanto. 2001. Administrasi Pendidikan. Rineka Cipta. Jakarta.

Robbins, Stephen P. \& Timothy A. Judge. 2008. Perilaku Organisasi. Edisi ke-12, Jakarta: Salemba Empat.

Syaiful Sagala. 2010. Supervisi Pembelajaran dalam Profesi Pendidikan. Alfabeta. Bandung.

Suchyadi, Y. (2017). Relationship between Work Motivation and Organizational Culture in Enhancing Professional Attitudes of Pakuan University Lecturers, 01(01). Retrieved from https://journal.unpak.ac.id/index.php/jhss/article/ view/372/296

T. Hani Handoko. 1985. Manajemen personalia dan sumber daya manusia. Penerbit Liberty. Jakarta. 